\title{
Sexual addiction, self-esteem and personality dimensions
}

\section{Badii Amamou ${ }^{1,2 *}$, Cyrine Missaoui ${ }^{1}$, Amjed Ben Haouala ${ }^{1}$, Ahmad Mhalla', Ferid Zaafrane ${ }^{1}$ and Lotfi Gaha ${ }^{1}$}

'Department of Psychiatry, University of Monastir, Monastir, Tunisia

${ }^{2}$ Tunisian Society of Clinical Sexology (TSCS), Tunisia

\section{Abstract}

Sexual addiction is a growing reality. The acknowledgment of this disorder requires to identify vulnerability factors. Besides, it would improve the management and treatment of these people. We used a cross-sectional study with a sample of voluntary subjects recruited online anonymously. A prepared questionnaire explored the general and clinical data of the sample. The psychometric scales used were: Carnes Sexual Addiction Screening Test, the French Big Five Inventory for personality dimensions and the Rosenberg Scale for self-esteem. Five hundred and ten individuals were included. 38 people $(8 \%)$ had sexual addiction. 68 people $(13 \%)$ had attenuated symptoms of sexual addiction. The average age of the group with sexual addiction was 30.8 years with a male predominance. The majority had a higher academic level, was single (39.5\%) and are working (73.7\%). Our study revealed that self-esteem was below average in $73.7 \%$ of people with sexual addiction. Concerning personality dimensions, individuals with sexual addiction had higher scores in Neuroticism. The analytic study showed that four variables were statistically correlated with sexual addiction: male sex; low self-esteem; a large $\mathrm{N}$ dimension and a low $C$ and $E$ dimension. The concept of sexual addiction, still poorly defined, is beginning to be recognized. The need for more research is required to identify the factors of vulnerability with the aim of developing the preventive axis and improving the quality of life.

\section{More Information}

*Address for Correspondence: Badii Amamou, Department of Psychiatry, University Hospital of Monastir (EPS Fattouma BOURGUIBA) Avenue Farhat HACHED 5000, Monastir, Tunisia, Tel: +216 73461141 (1485); +216 98475488; Email: amamoubadii@hotmail.fr; badii.amamou@rns.tn

Submitted: 13 February 2020 Approved: 19 February 2020 Published: 20 February 2020

How to cite this article: Amamou $B$, Missaoui C, Haouala AB, Mhalla A, Zaafrane F, et al. Sexual addiction, self-esteem and personality dimensions. J Addict Ther Res. 2020; 4: 006-012.

DOI: 10.29328/journal.jatr.1001011

ORCiD: orcid.org/0000-0001-5079-6252

Copyright: (C) 2020 Amamou B, et al. This is an open access article distributed under the Creative Commons Attribution License, which permits unrestricted use, distribution, and reproduction in any medium, provided the original work is properly cited.

Keywords: Addictive behavior; Sexual behavior; Self-esteem; Personality inventory

Check for updates

OPEN ACCESS

\section{Introduction}

There are as many standards for sexuality that that there are social, cultural and even religious norms. It was only in the late $19^{\text {th }}$ century that psychiatry took interest in hypersexuality. Kretschmer defined the category of 'frenetic masturbaters', while the first medical term is presented for the first time by Krafft-Ebing: sexual hyperesthesia [1]. In the late 1940s, Kinsey conducted a study on a population of more than 5000 people and created the term "total sexual outlets/ week" (TSO) to assess the frequency of sexual behavior [2]. A small proportion (7.6\%) asserted that they had a TSO/week greater than or equal to 7 over a period of 5 years. They were well above the average. Thus, the idea of hypersexuality came to light. There is a limited data on the prevalence of sexual addiction to establish solid estimations but according to an American study, it affects $3 \%$ to $6 \%$ of the general population [3]. Another study estimated the prevalence to $9.6 \%$ with a large male predominance [4]. Epidemiologic data are not available in Europe and in Middle East and North Africa. Socio-demographic characteristics alone cannot paint a full picture of vulnerability factors. Indeed, parts of personality have an important role in the onset of addiction [5]. Literature essentially reports a lack of self-esteem, social skills, selfloathing, dysfunctional copings and high excitement-seeking with low harm avoidance. The aims of our study were to determine the prevalence of sexual addiction in a Tunisian population, to consider the sociodemographic characteristics, the self-esteem and the personality dimensions of affected people and to identify the factors that could be associated to this addiction.

\section{Materials and method}

\section{Participants}

We conducted a cross-sectional survey online in an anonymous way over a period of three months (From 23 October 2016 to 8 February 2017). This study recruited Tunisian volunteers exclusively. At the end of the study, we collected 530 questionnaires. About twenty questionnaires have been removed, because the answers were either incomplete or duplicate. Accordingly, a total of 510 subjects aged between 16 and 65 years have been included on a voluntary and anonymous basis. Upper age limit has been set to 65 years to reduce the influence of age on cognitive or sexual impairments. Participants have been initially recruited 
through a social platform via several virtual groups on social media. A publication indicated the title of the study, its anonymous nature as well as the scientific framework in the field of psychiatry. The volunteers were redirected to a web link on Google.doc. The turnout was only $0.02 \%$.

\section{Measures}

Sociodemographic data were collected using a prepared questionnaire to explore general characteristics: age, gender, level of education, housing, marital status and employment situation.

\section{Sexual addiction}

Concerning psychometric assessments of sexual addiction, there are more than fifteen tools, with differences according to the studied concept: addiction or compulsive behavior, but also to psychometric properties and to the validity and reliability of the assessments [6]. In clinical practice, the most common scale is the Sexual Addiction Screening Test (SAST), the French validated version of this test was used in thus study. This test appears for the first time in the book Contrary To Love: Helping the Sexual Addict [7]. It was developed by Patrick Carnes and Robert Weiss to identify behaviors that may show sexual addiction. A score superior to 13 positive answers indicate that there is a sexual addiction issue. Thus, we can find three groups according to the score:

- A score inferior to 10 indicates that there are no sexual addiction issues.

- A score between 10 and 13 indicates the presence of attenuated symptoms of sexual addiction.

- A score superior to 13 indicates that there are sexual addiction issues.

\section{Self esteem}

Self-esteem was assessed using Rosenberg self-esteem scale [8], we used the French validated version of this scale. It is a four point Likert-type scale of ten items. The scale measures state self-esteem by asking the respondents to reflect on their current feelings. According to Rosenberg, selfesteem reflects the favorable or unfavorable attitude toward the self. It refers to an individual's sense of his or her value or worth, or the extent to which a person values, approves of, appreciates, prizes, or likes him or herself [9]. Self-esteem is generally considered the evaluative component of the selfconcept, a broader representation of the self that includes cognitive and behavioral aspects as well as evaluative or affective ones. It reflects more the person's perception of himself than the true reflection of reality. The assessment of self-esteem makes possible to evaluate to what extent one's beliefs affect its reality. It is the product of cohesion between aspirations and success [10]. A high self-esteem is an indicator of acceptance, self-satisfaction and self-respect.

\section{Personality dimensions}

One of the most used conceptions of personality dimension is the big five inventory personality. The Big Five Personality Factor Theory evaluates personality according to the five main factors of extraversion, agreeableness, conscientiousness, neuroticism and openness. This conception is well supported $[11,12]$. The Big Five Inventory (BFI) was created in 1991 by John Donahue and Kentle. The original version, made in English, include 44 items which are short sentences given in simple and accessible language. These items are associated with a Likert scale of 1 to 5. The BFI was developed to be quickly understood and filled. In our study, we used the French validated version of the Big Five Inventory (BFI-Fr), translated in French and validated [13]. The five main factors are defined as follows [14].

Extraversion (E): This dimension represents assertiveness, sociability and confidence. They are active and talkative people, which tend to be joyful. They are hopeful and dynamic. Low extraversion does not mean enmity, pessimism or lethargy. People with low extraversion are reserved, independent and studious. They seem quiet and less involved in the social world. These observations are well supported by research.

Agreeableness (A): Agreeableness relates to interpersonal interactions and reflects the degree of altruism. These persons are helpful and companionate. Low agreeableness is related to hostility, egocentrism and skepticism about others' intentions. People with low agreeableness are in competition spirit rather than cooperation. This dimension is socially beneficial, but it is not advantageous in competitive positions and to safeguard one's own interests. Critical thinking and skepticism are important for scientific research.

Neuroticism (N): Neuroticism reflects emotional instability and tendency to experience negative emotions, such as anger, anxiety, or depression. High neuroticism is linked to emotional reactivity and vulnerability to stress. These people tend to experience more negative life events and to have irrational beliefs. On the contrary, people with low neuroticism are tempered, cool and calm. They are less easily upset and are less emotionally reactive but that does not mean that low-scorers experience a lot of positive feelings. Neurotic people may have higher neuroticism but this dimension is not a measure of psychopathology. It is a normal part of personality. A high neuroticism does not mean to have a mental disorder and vice versa.

Conscientiousness (C): Conscientiousness is linked impulse control, organization and planning. These people are determined with a strong desire to succeed. Moreover, they are punctual, meticulous and reliable. High conscientiousness is associated to academic and professional success but may lead to compulsive behavior with burnout. Low conscientiousness does not mean a lack of moral principles. It's a tendency to sloppiness and lack of reliability but also flexibility and spontaneity. 
Openness (0): Openness reflects the degree of intellectual curiosity, creativity, aesthetic sensibility and a preference for novelty and variety a person has. These people are curious and more aware of their feelings. They are also more likely to hold unconventional beliefs. Low openness is linked to conventionality and pragmatism. It does not mean hostility which is more related to low agreeableness.

\section{Statistical analyzes}

Data were collected by using a software tool compatible with Excel. Then a statistical analysis was performed via SPSS 21.0 for Windows. We calculated relative frequencies for qualitative variables and means and standard deviations for quantitative variables. In the analytical study, SAST scores were subject to bivariate analysis with sociodemographic variables, self-esteem and personality dimensions (Chisquare/ANOVA/Spearman Coefficient). The confidence interval was of $95 \%$ and $p<0.05$ was taken as significant.

\section{Results}

In this cross-sectional study, five hundred and ten people were included. Our sample consisted of 360 women (60\%) and 204 men (40\%). The average age was $31.5+/-9.3$ years. Nearly all the population had a high level of education. 68 people $(13 \%)$ had attenuated symptoms of sexual addiction and 38 people (8\%) had sexual addiction as shown in figure 1.

We studied three populations:

Group 1 has no sexual addiction $(n=404)$

Group 2 has attenuated symptoms of sexual addiction $(n=68)$

Group 3 has sexual addiction $(n=38)$.

Evaluation of sociodemographic characteristics: Mean age was similar for all three groups (group 1: 31.5, group 2: 31.4 , and group 3: 30.8). There was a male dominance in groups 2 and 3 with a sex-ratio (M/W) respectively of 1.5 and 1.3. Nearly all of the population's groups had a high level of education and lived with family (group 1: $55 \%$, group 2: $54.4 \%$ and group $3: 44.7 \%)$. There were essentially married people in group 1 (35.6\%). In groups 2 and 3, single people

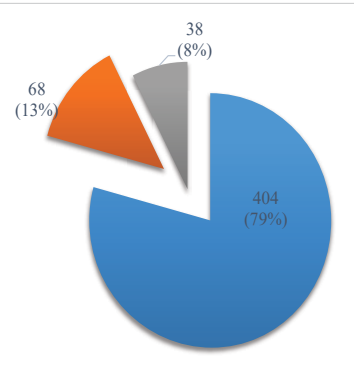

Figure 1: Distribution according to the degree of sexual addiction. were the most numerous in respectively $47.1 \%$ and $39.4 \%$. Into the three groups, the majority of people were in work (group 1: 64.9\%, group 2: 60.3\% and group 3: 73.7\%). Analysis study is shown in table 1 . We found that there is a significant difference between men and women $(p=0.00002)$. However, gender has a small influence on sexual addiction (Cramer's: 0.20 ). We do not found a statistically significant relationship between sexual addiction and age, level of education, housing, marital status and employment situation.

\section{Evaluation of self esteem}

Self-esteem in group 1 was either average or above in most cases (61.6\%). In group 2, self-esteem was below average in $61.8 \%$ of cases. In group 3, self-esteem was below average in $73.7 \%$ (low self-esteem in $47.4 \%$ of cases and very low selfesteem in $26.3 \%$ of cases). Moreover, Spearman coefficient is negative (Spearman coefficient $=-0.27 ; p<10-6$ ): the lower the self-esteem, the higher SAST score is as shown in table 2 .

\section{Evaluation of personality dimensions}

The population not presenting sexual addiction had higher scores in dimensions E, A and C. As shown in figure 2, the score of (A) was comparable between group 1 (3.65) and group 2 (3.62), the score of $(0)$ was comparable between group 1 (3.74) and group 2 (3.76), the score of (C) was comparable between group 2 (3.27) and group 3 (3.30). However, the score of $(n)$ was significantly higher in group 3 (3.61) compared to group 2 (3.23) and group 1 (2.94).

\begin{tabular}{|c|c|c|c|c|}
\hline & $\begin{array}{l}\text { No sexual } \\
\text { addiction } \\
n=404\end{array}$ & $\begin{array}{c}\text { Attenuated } \\
\text { symptoms } \\
n=68\end{array}$ & $\begin{array}{c}\text { Sexual } \\
\text { addiction } \\
n=38\end{array}$ & $\begin{array}{c}\text { Statistics : } \chi^{2} \text { or } \\
\text { ANOVA }\end{array}$ \\
\hline Mean age & 31.5 & 31.4 & 30.8 & $p=0.90$ \\
\hline $\begin{array}{l}\text { Gender: Men } \\
\text { Women }\end{array}$ & $\begin{array}{l}141(34.9 \%) \\
263(65.1 \%)\end{array}$ & $\begin{array}{l}41(60.3 \%) \\
27(39.7 \%)\end{array}$ & $\begin{array}{l}22(57.9 \%) \\
16(42.1 \%)\end{array}$ & $\begin{array}{c}p<10^{-4} \\
\text { Cramer's' V }=0.20\end{array}$ \\
\hline $\begin{array}{l}\text { Level of education } \\
\text { Primary } \\
\text { Secondary } \\
\text { Tertiary }\end{array}$ & $\begin{array}{c}1(0.2 \%) \\
14(3.5 \%) \\
389(96.3 \%)\end{array}$ & $\begin{array}{c}0 \\
0 \\
68\end{array}$ & $\begin{array}{c}0 \\
2(5.3 \%) \\
36(94.7 \%)\end{array}$ & $p=0.52$ \\
\hline $\begin{array}{c}\text { Housing } \\
\text { Alone } \\
\text { Collocation/friends } \\
\text { In couple/In family }\end{array}$ & $\begin{array}{l}69(17.1 \%) \\
36(8.9 \%) \\
299(74 \%)\end{array}$ & $\begin{array}{c}11(16.2 \%) \\
7(10.3 \%) \\
50(73.5 \%)\end{array}$ & $\begin{array}{c}8(21.1 \%) \\
4(10.5 \%) \\
26(68.4 \%)\end{array}$ & $p=0.95$ \\
\hline $\begin{array}{l}\text { Marital status } \\
\text { Non married } \\
\text { Married }\end{array}$ & $\begin{array}{l}260(64.5 \%) \\
144(35.6 \%)\end{array}$ & $\begin{array}{l}48(70.9 \%) \\
20(29.4 \%)\end{array}$ & $\begin{array}{l}28(73.7 \%) \\
10(26.3 \%)\end{array}$ & $p=0.52$ \\
\hline $\begin{array}{l}\text { Employment } \\
\text { situation } \\
\text { Student } \\
\text { Working } \\
\text { Unemployed } \\
\text { Retired }\end{array}$ & $\begin{array}{c}112(27.7 \%) \\
262(64.9 \%) \\
24(5.9 \%) \\
6(1.5 \%)\end{array}$ & $\begin{array}{c}24(35.3 \%) \\
41(60.3 \%) \\
3(4.4 \%) \\
0\end{array}$ & $\begin{array}{c}9(23.7 \%) \\
28(73.7 \%) \\
1(2.6 \%) \\
0\end{array}$ & $p=0.59$ \\
\hline
\end{tabular}

\begin{tabular}{|c|c|c|c|c|}
\hline $\begin{array}{c}\text { Self } \\
\text { esteem }\end{array}$ & $\begin{array}{l}\text { No sexual } \\
\text { addiction } \\
n=404\end{array}$ & $\begin{array}{c}\text { Attenuated } \\
\text { symptoms } \\
n=68\end{array}$ & $\begin{array}{c}\text { Sexual } \\
\text { addiction } \\
n=38\end{array}$ & $\begin{array}{c}\text { Statistics : } \chi^{2} \text { or } \\
\text { Spearman }\end{array}$ \\
\hline Very low & $50(12.4 \%)$ & $14(20.6 \%)$ & $10(26.3 \%)$ & \multirow{5}{*}{$\begin{array}{c}\chi^{2}(p=0.0001) \\
\text { Cramer's V: } 0.24 \\
\text { Spearman } \\
\text { Coefficient: }-0,27 \\
\quad(p<10-6)\end{array}$} \\
\hline Low & $105(26.0 \%)$ & $28(41.2 \%)$ & $18(47.4 \%)$ & \\
\hline Average & $83(20.5 \%)$ & $11(16.2 \%)$ & $3(7.9 \%)$ & \\
\hline High & $131(32.4 \%)$ & $15(22.1 \%)$ & $5(13.2 \%)$ & \\
\hline Very High & $35(8.7 \%)$ & 0 & $2(5.4 \%)$ & \\
\hline
\end{tabular}


There is no correlation between sexual addiction and dimensions $\mathrm{A}$ and $\mathrm{O}$. However, there is a significant difference between the means of $(\mathrm{N})$ in group 1 and the two other groups. This correlation is positive (Spearman coefficient: 0.22 ) which means that the upper the score of $(\mathrm{N})$, the higher SAST's score is as shown in table 3. On the other hand, no statistical differences were observed between group 2 and group 3 in scores of $(\mathrm{N})$. Concerning the dimension (C), statistically significant differences were found between group 1 and group 2 with a negative correlation between (C) and SAST score (Spearman coefficient: - 0.20). The same applies to dimension (E) (Spearman coefficient: - 0.12). The small sample size of group $3(n=38)$ may explain the lack of statistical significance of the ad-hoc tests when comparing (E) and (C) with group 1. Correlation between SAST's score and dimensions (E) and (C) is negative: The lower scores of (E) and (C), the higher SAST's score is as shown in table 3.

\section{Discussion}

The assessment of the characteristics of people with sexual addiction has been little studied. The lack of medical evidence in Tunisia prompted us to focus on it. Our work is based on a cross-sectional study, which is certainly easy to perform. Nevertheless, because of the limited duration, it does not allow a longitudinal vision of the phenomenon and do not explore cause and effect relationship. As similar reviews $[15,16]$, our survey was carried out online in anonymity. This method has some merits: low cost, less errors during data

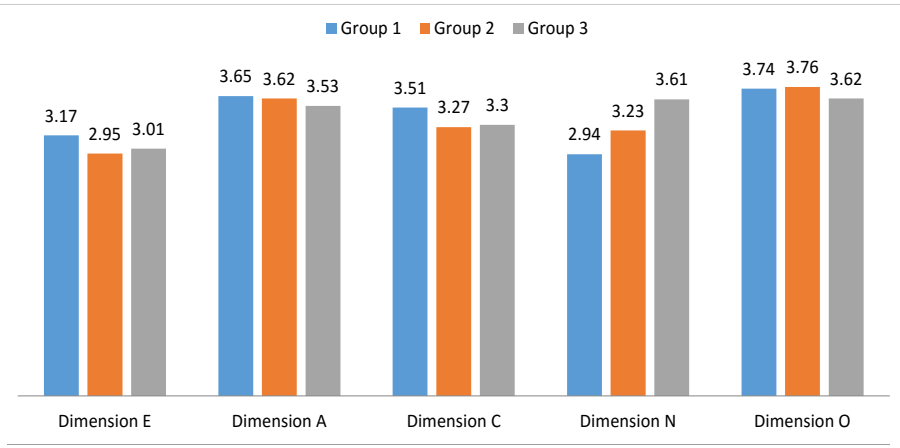

Figure 2: Distribution of personality dimensions according to SAST's score.

\begin{tabular}{|c|c|c|c|c|c|c|c|}
\hline \multicolumn{2}{|c|}{$\begin{array}{l}\text { Personality } \\
\text { dimensions }\end{array}$} & Means & $\begin{array}{l}\text { Standard } \\
\text { deviation }\end{array}$ & $\begin{array}{c}\text { Levene's } \\
\text { test }\end{array}$ & $\begin{array}{c}\text { Sig } \\
\text { ANOVA }\end{array}$ & Ad-hoc tests & $\begin{array}{l}\text { Spearman } \\
\text { coefficient }\end{array}$ \\
\hline $\begin{array}{c}\text { Dimension } \\
\mathrm{E}\end{array}$ & $\begin{array}{l}\text { Group } 1 \\
\text { Group } 2 \\
\text { Group } 3\end{array}$ & $\begin{array}{l}3.17 \\
2.95 \\
3.01\end{array}$ & $\begin{array}{l}0.73 \\
0.84 \\
0.74\end{array}$ & 0.13 & 0.04 & $\begin{array}{l}\text { G1/G2 } p: 0.05 \\
\text { G1/G3 } p: 0.39 \\
\text { G2/G3 } p: 0.92\end{array}$ & $\begin{array}{c}-0,12 \\
p: 0.007\end{array}$ \\
\hline $\begin{array}{c}\text { Dimension } \\
\mathrm{A}\end{array}$ & $\begin{array}{l}\text { Group } 1 \\
\text { Group } 2 \\
\text { Group } 3\end{array}$ & $\begin{array}{l}3.65 \\
3.62 \\
3.53\end{array}$ & $\begin{array}{l}0.57 \\
0.52 \\
0.59\end{array}$ & 0.75 & 0.47 & & \\
\hline $\begin{array}{c}\text { Dimension } \\
\text { C }\end{array}$ & $\begin{array}{l}\text { Group } 1 \\
\text { Group } 2 \\
\text { Group } 3\end{array}$ & $\begin{array}{l}3.51 \\
3.27 \\
3.30\end{array}$ & $\begin{array}{l}0.61 \\
0.53 \\
0.64\end{array}$ & 0.53 & 0,003 & $\begin{array}{c}\text { G1/G2 } p: 0.008 \\
\text { G1/G3 } p: 0.10 \\
\text { G2/G3 } p: 0.97\end{array}$ & $\begin{array}{c}-0.20 \\
p<10-5\end{array}$ \\
\hline $\begin{array}{c}\text { Dimension } \\
\mathrm{N}\end{array}$ & $\begin{array}{l}\text { Group } 1 \\
\text { Group } 2 \\
\text { Group } 3\end{array}$ & $\begin{array}{l}2.93 \\
3.23 \\
3.61\end{array}$ & $\begin{array}{l}0.76 \\
0.74 \\
0.94\end{array}$ & 0.26 & $<10-6$ & $\begin{array}{l}\text { G1/G2 } p: 0.01 \\
\text { G1/G3 } p: 10-6 \\
\text { G2/G3 } p: 0.10\end{array}$ & $\begin{array}{c}0.22 \\
p<10-6\end{array}$ \\
\hline $\begin{array}{c}\text { Dimension } \\
0\end{array}$ & $\begin{array}{l}\text { Group } 1 \\
\text { Group } 2 \\
\text { Group } 3\end{array}$ & $\begin{array}{l}3.74 \\
3.76 \\
3.62\end{array}$ & $\begin{array}{l}0.62 \\
0.63 \\
0.75\end{array}$ & 0.15 & 0.47 & & \\
\hline
\end{tabular}

entry, more individual freedom while answering and the democratization of research [17]. Concerning survey response quality, there is a division of views. However, respondents tend to tell more about themselves and less biased because of social acceptability [18]. Another advantage is the timeliness of data entry. Nevertheless, it is important to mention the limits encountered in practice: the emotional state of people during the survey and no standardized evaluation conditions. Moreover, our sample is not sufficiently representative of general population.

\section{Prevalence}

Prevalence of sexual addiction varies from $3 \%$ to $6 \%$, according to American and Australian studies [3]. Until today, we did not found any epidemiological studies in Tunisia. Prevalence found in our survey was $8 \%$. This estimation is higher than in other studies. This could be explained by anonymity of responders, allowing a free expression.

\section{Socio-demographic characteristics}

In order to properly understand addictions, interactions between the object of addiction, the subject and the surrounding environment should be taken into account. In this sense, many studies explored vulnerability factors. These factors vary between individuals, so people are not equal when it comes to addictions. Concerning individual factors, we explored sociodemographic characteristics of our population. Mean age was about 30 years and there is a male dominance in groups with sexual addiction or attenuated symptoms. These results are similar to other studies [19-21]. Odlaug, et al. found that $3 \%$ of men and $1 \%-2 \%$ of women had sexual addiction [22]. This male dominance has also been found with in-patients at psychiatric hospitals [23]. Ross, et al. estimated prevalence of sexual addiction online at $2 \%$ for women and $5 \%$ for men [16]. Thus, the prevalence of sexual addiction is about twice as common in men than in women. This may be explained by socio-cultural context which is patriarchal and religious. Moreover, women's sexuality remains today a taboo subject and women are reluctant to talk about it. The assessment of behavioral addictions and what is more sexual is difficult. It is often hampered by embarrassment and shame [24]. Concerning marital status, the group with sexual addiction was mainly single but we did not found correlations in analytical study. Data from the literature is balanced as to the relationship between marital status and sexual addiction. If some surveys did not found any correlations $[25,26]$, others emphasize the opposite [19]. Sexual addiction often leads to separation and divorce and may be symptomatic of intimacy problems $[27,28]$. The partner often has a low selfesteem and feelings of mistrust, betrayal and shame [29]. Time spent watching pornographic content may lead to a bad representation of the other which is considered as an object $[30,31]$. Furthermore, sexual addiction could decrease sexual desire within couples: $16 \%$ of partners, $34 \%$ of addicts and $18 \%$ of both addict and partner. Only $32 \%$ did not feel 
loss of sexual desire. In our study, the lack of statistically significant results might be explained by a relatively small number of addicts. Level of education was mainly tertiary, and we could not find any correlations with sexual addiction. Many authors, however, report that most of addicted people have a high level of education [16,26]. Correlations between housing, employment situation and sexual addiction were not significant. All social and professional backgrounds are involved [32].

\section{Personality dimensions}

We did not find any survey exploring relationship between personality dimensions and sexual addiction but many have studied drug addiction. It was considered relevant to compare these findings with ours to better identify similarities between sexual addiction and other type of addictions. Among smokers, there is a positive correlation with impulsivity and neuroticism and a negative correlation with dimensions $\mathrm{A}$ and $C[33,34]$. Alcoholics have a high neuroticism with low scores in dimensions E and C [35-37]. People with opioid addiction, have a high neuroticism with low conscientiousness and extraversion [38-40]. Cocaine addicts have high scores in neuroticism, depression and impulsivity with low conscientiousness and agreeableness [41,42]. Results for pathological gambler were similar [43]. Our findings were in good agreement with the data from the literature. People with high neuroticism tend to be pessimistic, anxious with feelings of guilt and dissatisfaction. They are predisposed to psychological distress and more sensitive to unpleasant aspects of life [44]. A low conscientiousness is correlated to craving in alcoholics [45]. People with low conscientiousness do not handle stress and lack of immediate reward well.

\section{Self esteem}

We found a negative correlation between sexual addiction and self-esteem. However, this link of causality remains unclear. Does a low self-esteem trigger the onset of addictions? Or does sexual addiction alter self-esteem? Conventionally, addiction is characterized by the loss of the capacity to refrain from consuming substances or having activities which create dependence. Thus, there is a loss of control of one's own behavior with a feeling of no self-efficacy. Repeating such failures may result in a decrease in self-esteem [46]. However, it is suggested that sexual addiction would serve to alleviate or to repair a childhood trauma [47]. It can be a mourning, an ill-treatment or sexual abuse [48]. Carnes emphasized the role of sexual abuse during childhood in the onset of sexual addiction during adulthood [49]. This conclusion was further supported by Ferree [50] and Giugliano [51]. Sexuality is an essential component in the in life for every individual. Therefore, dysfunctional sexualization needs to be explored. The presence of traumatic events and Attachment disorder during childhood fosters the earliness of sexual initiation, the frequency of sexual behaviors and the diversity of sexual experiences [52].

\section{Conclusion}

Distress relating to the sexual addiction began to gain recognition over the past years. It is essential to assess etiological and diagnostic aspects and to identify vulnerability with the aim of developing the preventive axis. Moreover, the exploration of these factors allows better therapeutic strategies.

\section{Compliance with ethical standards}

We have no conflict of interest to declare. All procedures performed in studies involving human participants were in accordance with the ethical standards of the institutional and/ or national research committee and with the 1964 Helsinki declaration and its later amendments or comparable ethical standards. Informed consent was obtained from all individual participants included in the study.

\section{References}

1. Krafft ER, Klaf FS. Psychopathia sexualis: with especial reference to the antipathic sexual instinct: a medico-forensic study: Arcade Publishing. 1965.

2. Kinsey AC, Pomeroy WB, Martin CE, Sloan S. Sexual behavior in the human male. 1948.

3. Kuzma JM, Black DW. Epidemiology, prevalence, and natural history of compulsive sexual behavior. Psychiatr Clin North Am. 2008; 31: 603611.

PubMed: https://www.ncbi.nlm.nih.gov/pubmed/18996301

4. Skegg K, Nada-Raja S, Dickson N, Paul C. Perceived "out of control" sexual behavior in a cohort of young adults from the Dunedin Multidisciplinary Health and Development Study. Arch Sex Behav. 2010; 39: 968-978. PubMed: https://www.ncbi.nlm.nih.gov/pubmed/19421850

5. Chakroun N, Doron J, Swendsen J. Substance use, affective problems and personality traits: test of two association models. L'Encephale. 2003; 30: 564-569.

PubMed: https://www.ncbi.nlm.nih.gov/pubmed/15738859

6. Hook JN, Hook JP, Davis DE, Worthington Jr, Penberthy JK. Measuring sexual addiction and compulsivity: A critical review of instruments. $J$ Sex Marital Ther. 2010; 36: 227-260.

PubMed: https://www.ncbi.nlm.nih.gov/pubmed/20432124

7. Aaron M. The pathways of problematic sexual behavior: A literature review of factors affecting adult sexual behavior in survivors of childhood sexual abuse. Sexual Addiction \& Compulsivity. 2012; 19: 199-218

8. Vallieres EF, Vallerand RJ. Traduction et validation canadiennefrançaise de l'échelle de l'estime de soi de Rosenberg. International journal of psychology. 1990; 25: 305-316.

9. Rosenberg M. Conceiving the self-New York: Basic. Rosenberg Conceiving the Self. 1979.

10. Bourgeois ML, Berrios GE. L'anhédonie: le non-plaisir et la psychopathologie: Masson. 1999.

11. Bouvard M. Questionnaires et échelles d'évaluation de la personnalité: Elsevier Masson. 2009.

12. Costa P, McCrae R, Rolland J. NEO-PI-R. Inventaire de Personnalité révisé. Adaptation FranÇaise. P. Rolland. Editions du Centre de Psychologie Appliquée, Paris. 1998. 
13. Plaisant $O$, Courtois R, Réveillère $C$, Mendelsohn G, John O. Validation par analyse factorielle du Big Five Inventory français (BFI-Fr). Analyse convergente avec le NEO-PI-R. Paper presented at the Annales Médicopsychologiques, revue psychiatrique. 2010.

14. McCrae RR, Costa PT. Validation of the five-factor model of personality across instruments and observers. J Pers Soc Psychol. 1987; 52: 81. PubMed: https://www.ncbi.nlm.nih.gov/pubmed/3820081

15. Albright JM. Sex in America online: An exploration of sex, marita status, and sexual identity in Internet sex seeking and its impacts. $J$ Sex Res. 2008; 45: 175-186.

PubMed: https://www.ncbi.nlm.nih.gov/pubmed/18569538

16. Ross MW, Månsson SA, Daneback K. Prevalence, severity, and correlates of problematic sexual Internet use in Swedish men and women. Arch Sex Behav. 2012; 41: 459-466

PubMed: https://www.ncbi.nlm.nih.gov/pubmed/21562915

17. Kaplowitz MD, Hadlock TD, Levine R. A comparison of web and mail survey response rates. Public opinion quarterly. 2004; 68: 94-101.

18. Gingras MÈ, Belleau $H$. Avantages et désavantages du sondage en ligne comme méthode de collecte de données: une revue de la littérature. 2015.

19. Ballester-Arnal $R$, Castro-Calvo J, Gil-Llario MD, Giménez-García $C$. Relationship status as an influence on cybersex activity: Cybersex youth, and steady partner. J Sex Marital Ther. 2014; 40: 444-456. PubMed: https://www.ncbi.nlm.nih.gov/pubmed/24134331

20. Kafka MP. Hypersexual disorder: A proposed diagnosis for DSM-V. Arch Sex Behav. 2010; 39: 377-400.

PubMed: https://www.ncbi.nlm.nih.gov/pubmed/19937105

21. Mick TM, Hollander E. Impulsive-compulsive sexual behavior. CNS Spectr. 2006; 11: 944-955.

PubMed: https://www.ncbi.nlm.nih.gov/pubmed/17146408

22. Odlaug BL, Lust K, Schreiber L, Christenson G, Derbyshire K, et al Compulsive sexual behavior in young adults. Ann Clin Psychiatry. 2013, 25: $193-200$

PubMed: https://www.ncbi.nlm.nih.gov/pubmed/23926574

23. Müller A, Rein K, Kollei I, Jacobi A, Rotter A, et al. Impulse control disorders in psychiatric inpatients. Psychiatry Res. 2011; 188: 434-438. PubMed: https://www.ncbi.nlm.nih.gov/pubmed/21546096

24. Black DW, Kehrberg LL, Flumerfelt DL, Schlosser SS. Characteristics of 36 subjects reporting compulsive sexual behavior. Am J Psychiatry. 1997; 154: 243-249.

PubMed: https://www.ncbi.nlm.nih.gov/pubmed/9016275

25. Cooper A, Scherer CR, Boies SC, Gordon BL. Sexuality on the Internet From sexual exploration to pathological expression. Professional Psychology: Research and Practice. 1999; 30: 154.

26. Daneback K, Cooper A, Månsson SA. An Internet study of cybersex participants. Archives of sexual behavior. 2005; 34: 321-328.

27. Cooper A, Marcus I. Men who are not in control of their sexual behavior. Handbook of clinical sexuality for mental health professionals. 2003 311-332.

28. Schneider JP, Weiss R, Samenow C. Is it really cheating? Understanding the emotional reactions and clinical treatment of spouses and partners affected by cybersex infidelity. Sexual Addiction \& Compulsivity. 2012 19: $123-139$

29. Meili W, Pfeifer S. Internet, sexe et dépendance. Paper presented at the Clinique et traitement de la dépendance au sexe sur Internet. Forum Medical Suisse. 2011

30. Barak A, Fisher WA, Cooper A. The future of Internet sexuality. Sex and the Internet: A guide book for clinicians. 2002; 267-280.
31. Harris RJ. The impact of sexually explicit media. Media effects: Advances in theory and research. 1994; 247-272.

32. Chansin AG. Pratiques actuelles et connaissances utiles au médecin généraliste dans le domaine des addictions comportementales: étude chez 53 médecins généralistes du Havre concernant 6 addictions sans drogue (jeu pathologique, achats compulsifs, addiction à l'internet addiction au travail, addiction à l'exercice physique et addiction au sexe). 2012.

33. Malouff JM, Thorsteinsson EB, Schutte NS. The five-factor model of personality and smoking: A meta-analysis. J Drug Educ. 2006; 36: 47-58. PubMed: https://www.ncbi.nlm.nih.gov/pubmed/16981639

34. Terracciano A, Costa PT. Smoking and the Five-Factor Model of personality. Addiction. 2004; 99: 472-481.

PubMed: https://www.ncbi.nlm.nih.gov/pubmed/15049747

35. Coëffec A. Les apports du modèle des cinq grands facteurs dans le domaine de l'alcoolodépendance. L'Encephale. 2011; 37: 75-82.

36. Coëffec A, Romo L, Strika L. Personnalité et impulsivité: Étude portant sur 20 patients alcoolodépendants. Alcoologie et addictologie. 2009; 31: $327-332$.

37. Repetti RL, Taylor SE, Seeman TE. Risky families: family social environments and the mental and physical health of offspring. Psychol Bull. 2002; 128: 330 .

PubMed: https://www.ncbi.nlm.nih.gov/pubmed/11931522

38. Carter JA, Herbst JH, Stoller KB, King VL, Kidorf MS, et al. Short-term stability of NEO-PI-R personality trait scores in opioid-dependent outpatients. Psychol Addict Behav. 2001; 15: 255.

PubMed: https://www.ncbi.nlm.nih.gov/pubmed/11563805

39. Kornør $\mathrm{H}$, Nordvik $\mathrm{H}$. Five-factor model personality traits in opioid dependence. Bmc Psychiatry. 2007; 7: 37.

PubMed: https://www.ncbi.nlm.nih.gov/pubmed/17683593

40. Trémeau F, Darreye A, Leroy B, Renckly V, Ertle S, et al. Personality changes in opioid-dependent subjects in a methadone maintenance treatment program. L'Encephale. 2002; 29: 285-292.

PubMed: https://www.ncbi.nlm.nih.gov/pubmed/14615698

41. Rosenthal TL, Edwards NB, Ackerman BJ, Knott DH, Rosenthal RH Substance abuse patterns reveal contrasting personal traits. J Subst Abuse. 1990; 2: 255-263.

PubMed: https://www.ncbi.nlm.nih.gov/pubmed/2136114

42. Sáiz P, González M, Paredes B, Martínez S, Delgado J. Personality and use-abuse of cocaine. Adicciones. 2001; 13

43. Miller JD, MacKillop J, Fortune EE, Maples J, Lance CE, et al. Personality correlates of pathological gambling derived from Big Three and Big Five personalitymodels. Psychiatry Res. 2013; 206: 50-55.

PubMed: https://www.ncbi.nlm.nih.gov/pubmed/23078872

44. Julien-Daniel G, Patrick H. Les personnalités pathologiques: Lavoisier. 2013.

45. Zilberman ML, Tavares H, El-Guebaly N. Relationship between craving and personality in treatment-seeking women with substance-related disorders. Bmc Psychiatry. 2003; 3: 1.

PubMed: https://www.ncbi.nlm.nih.gov/pubmed/12525264

46. Rousselet $A V$, Laqueille $X$. De l'addiction à la dissociation corporelle et psychique. Laennec. 2016; 64: 29-41.

47. Bergner RM, Bridges AJ. The significance of heavy pornography involvement for romantic partners: Research and clinical implications. J Sex Marital Ther. 2002; 28: 193-206.

PubMed: https://www.ncbi.nlm.nih.gov/pubmed/11995598

48. Beraud J, Marcelli D, Venisse J, Reynaud M. Les facteurs psychosociaux de 
risque, de gravité et de protection. M Reynaud. Usage nocif de substances psychoactives. Paris La Documentation Franaise. 2002; 59-77.

49. Carnes P. Don't call it love: Recovery from sexual compulsion. New York. 1991.

50. Ferree M. Women and the web: Cybersex activity and implications. Sexual and Relationship Therapy. 2003; 18: 385-393.
51. Giugliano J. Out of control sexual behavior: A qualitative investigation. Sexual Addiction \& Compulsivity. 2006; 13: 361-375.

52. Långström N, Hanson RK. High rates of sexual behavior in the general population: Correlates and predictors. Archives of sexual behavior. 2006; 35: 37-52.

PubMed: https://www.ncbi.nlm.nih.gov/pubmed/16502152 